\title{
MORALNO-PASTORALNO DJELOVANJE CRKVE PRED IZAZOVOM ISELJAVANJA I PADA NATALITETA U ISTOČNOJ HRVATSKOJ
}

\author{
Vladimir Dugalić - Dražen Živić
}

Sveučilište u Osijeku

Katolički bogoslovni fakultet u Đakovu vladimir.dugalic@djkbf.hr

Institut društvenih znanosti Ivo Pilar

Područni centar u Vukovaru

Drazen.Zivic@pilar.hr
UDK: 27-46:331.556(497.54)

27-46:314.3(497.54)

https://doi.org/10.34075/cs.55.3.5

Izvorni znanstveni rad

Rad zaprimljen 9/2020.

\section{Sažetak}

Istok Hrvatske danas se suočava sa sve većim valom iseljavanja koji, uz već više desetljeća snažnu depopulaciju, ove krajeve stavlja $u$ vrlo nepovoljnu situaciju. U prvom dijelu rada analiziraju se stoga migracijski trendovi i razmjeri depopulacije kao i najvažniji uzroci koji su doveli do ove situacije te se ističu i neke nužne pronatalitetne i gospodarske mjere. Naime, u razdoblju od 2011. do 2018. godine istočnohrvatske županije ostvarile su negativan saldo vanjske migracije od (najmanje) 46.606 stanounika, što je u odnosu na ukupan broj stanounika 2011. godine 5,8 \%, pri čemu, očekivano, prednjače Osječko-baranjska i Vukovarsko-srijemska županija. Međutim, neka istraživanja pokazuju da je stvarni broj iseljenih iz Hrvatske $u$ inozemstvo možda i do tri puta veći od službenoga broja. U drugom dijelu rada ističe se važnost moralno-pastoralnog i socijalno-karitativnog djelovanja Crkve, osobito u pronalaženju odgovora na sve češće obiteljske migracije, ali i u iznalaženju novih oblika pastoralne skrbi za iseljene. Crkva je pozvana, s jedne strane, duhovno-pastoralno pratiti one koji su otišli $u$ inozemstvo te im poručiti kako nisu zaboravljeni i da se s radošću čeka njihov povratak, a s druge, pozivati mlade ljude i obitelji da ostanu u svojoj zemlji i tu grade svoju budućnost. Osim toga, u situaciji snažne depopulacije Crkva ima zadaću, snagom svoga proročko-evangelizacijskog poslanja, promicati „evanđelje obitelji" i poticati mentalitet u kojem se dijete promatra kao dar, a ne teret za obitelj. Reorganizacija pastorala braka i obitelji te iznala- 
ženje novih oblika karitativnog djelovanja, nameću se kao prioriteti moralno-pastoralnog djelovanja Crkve.

Ključne riječi: Istočna Hrvatska, iseljavanje, migracijski trendovi, depopulacija, pronatalitetna politika, Katolička Crkva, evanđelje obitelji, kultura života, pastoral braka i obitelji, karitativno djelovanje.

\section{UVOD}

Desetljećima je prostor Istočne Hrvatske, koji danas s crkvenoga gledišta obuhvaćaju Đakovačko-osječka nadbiskupija i Požeška biskupija, a administrativno uokviruju Brodsko-posavska, Osječkobaranjska, Požeško-slavonska, Virovitičko-podravska i Vukovarskosrijemska županija, bio obećana zemlja u koju se rado doseljavalo u potrazi za boljim životom i sigurnijom osobnom i obiteljskom egzistencijom. No danas je Istočna Hrvatska jako žarište depopulacije, iseljavanja i ostarjelosti stanovništva, s negativnim demografskim trendovima i procesima koji dominantno imaju depopulacijska obilježja. ${ }^{1}$ Drugim riječima, danas se suočavamo s dva velika, međusobno povezana problema koja dugoročno stavljaju ove krajeve $u$ vrlo nepovoljan položaj. U ovom radu pokušat ćemo stoga prikazati razmjere depopulacije i iseljavanja, uputiti na najvažnije uzroke koji su doveli do ove situacije te istaknuti izazove s kojima se suočava Crkva u Istočnoj Hrvatskoj kao i određena područja njezina djelovanja i pokušaje transformacije pastoralnog rada $u$ novonastalim okolnostima.

\section{IZAZOVI DEPOPULACIJE I SNAŽNIH MIGRACIJSKIH TRENDOVA}

Povijesno gledajući, iako je istočnohrvatsko područje često stoljećima bilo poprištem ratnih sukoba, brojnih i strukturno složenih migracija te političkih i teritorijalnih promjena, njegove su prirodne datosti, poput odličnog geoprometnog položaja, kvalitetne zemlje, velikog šumskog bogatstva, brojnih rijeka i sl. poticale doseljavanja, a time i demografski napredak cijeloga kraja. Doduše, jake su stoljećima bile i iseljeničke struje istočnohrvatskoga stanovništva zbog specifičnoga povijesno-političkog razvoja koji je i demografske trendove i odnose znao usmjeriti u silaznu putanju. Tako je samo u XX. stoljeću bilo nekoliko velikih emigracijskih valova povezanih

1 Dražen Živić, Depopulacija i starenje u Istočnoj Hrvatskoj, Diacovensia 26 (2018) 4, 657-679. 
uz političke, društvene, demografske i ekonomske posljedice I. i II. svjetskoga rata, uz odlazak na tzv. privremeni rad $\mathrm{u}$ inozemstvo 1960-ih i kasnijih godina, uz ruralni egzodus osobito jak od 1950-ih do 1970-ih godina koji i danas „odjekuje” u demografskoj slici Istočne Hrvatske, uz Domovinski rat 1990-ih i brojne prisilne migracijske ratne struje, pri čemu se dio prognanih i izbjeglih osoba po okončanju ratnoga stanja i okupacije nije vratio u svoja prijeratna prebivališta, te uz recentnu stagnaciju pa i razvojno zaostajanje za drugim dijelovima Hrvatske kao osobito snažnim push faktorom iseljavanja. ${ }^{2}$

U novije vrijeme jačaju razvojne „napetosti” između županija Istočne Hrvatske i drugih hrvatskih županija, što je povoljan uzročno-motivacijski okvir za jačanje iseljavanja. Ako tome pridodamo i ulazak Hrvatske u Europsku uniju 1. srpnja 2013. godine te otvaranje tržišta rada u razvijenim europskim zemljama i za radnike iz Hrvatske, onda je jasno da su se ispunili svi preduvjeti za nastavak ionako desetljećima jake hrvatske ekonomske emigracije. ${ }^{3}$ No opći demografski uvjeti u Hrvatskoj iz kojih se „mobilizira” današnji iseljenički val daleko su nepovoljniji negoli prije pedesetak godina, iz čega jasno proizlazi da će i posljedice suvremenog egzodusa ostaviti

2 Domovinski rat samo je produbio tešku demografsku situaciju jer se velik broj prognanih (približno $50 \%$ ) nije vratio u svoje domove te su slavonska sela postala mjesta s izrazito staračkim življem. Sve brojnije iseljavanje kako u druge hrvatske krajeve tako i u inozemstvo, praćeno sve nepovoljnijim trendovima $\mathrm{u}$ prirodnoj dinamici stanovništva i sve intenzivnijim starenjem stanovništva, rezultiralo je usporavanjem stopa demografskoga porasta, a onda i pojavom ukupne depopulacije, odnosno međupopisnoga pada broja stanovnika koju statistički za svih pet županija možemo pratiti u kontinuitetu od 1991. godine, s tim da su neke istočnohrvatske županije, poput Virovitičko-podravske, u opću i emigracijsku depopulaciju ušle i ranije. „Demografi podsjećaju da su desetljećima prije bezuspješno upozoravali na negativna demografska kretanja, koja bi i bez srbijanske agresije dovela do ovakvih negativnih učinaka, a agresija ih je samo uvećala.", Josip Jurčević, Povijesni čimbenici depopulacije (istočne) Hrvatske, u: Pero Aračić (ur.), Kamo ide istočna Hrvatska? Demografsko stanje, prognoze i traženje izlaska iz krize Slavonije, Baranje i zapadnog Srijema. Zbornik radova, HAZU, ZagrebĐakovo, 2018., 130.

3 Ulazak Republike Hrvatske u Europsku uniju dodatno je omogućio val iseljavanja, jer ne odlaze samo oni koji zbog siromaštva i nezaposlenosti ne uspijevaju sebi osigurati sigurnu i uspješnu budućnost na ovim prostorima, nego je i sve više onih koji odlaze tražeći bolji životni standard koji ovdje ne bi mogli ostvariti. Ne smiju se zanemariti ni posljedice stradanja hrvatskog stanovništva u Bosni i Hercegovini, osobito tijekom posljednjeg rata, jer, nakon više stoljeća, ti krajevi više nisu u mogućnosti migracijama hrvatskog življa u Slavoniju, Baranju i Srijem nadomjestiti manjak stanovništva koji je ovdje nastajao uslijed pada nataliteta i iseljavanja. Naime, „već sada je potpuno razvidno da je vanjska migracija, tj. da su dramatični razmjeri sve većeg doslovno iseljeničkog 'stampeda' iz svih dijelova Hrvatske i s hrvatskog prostora iz BiH postali kudikamo najbitniji čimbenik demografskog kretanja”. Isto, 132. 
teže i trajnije posljedice, ne samo u demografskom nego i u širem društveno-gospodarskom kontekstu.

\subsection{Depopulacijski i migracijski (iseljenički) trendovi}

Sve brojnije iseljavanje kako u druge hrvatske krajeve tako i u inozemstvo, praćeno sve nepovoljnijim trendovima u prirodnoj dinamici stanovništva i sve intenzivnijim starenjem populacije, rezultiralo je prvo snižavanjem stopa demografskoga porasta, a onda i pojavom ukupne depopulacije, odnosno međupopisnoga pada broja stanovnika koju statistički za Istočnu Hrvatsku u cjelini kao i za svih pet njezinih županija, neovisno je li riječ o ukupnom ili prisutnom stanovništvu (stanovništvu „u zemlji”), možemo pratiti u kontinuitetu od 1991. godine (tablice 1 i 2), s tim da su dvije istočnohrvatske županije (Virovitičko-podravska i Požeško-slavonska) u opću i emigracijsku depopulaciju ušle i ranije.

Prema kriteriju ukupnoga stanovništva stopa depopulacije Istočne Hrvatske u razdoblju 1991. - 2011. godine iznosila je $-17,5$ $\%$, a prema kriteriju prisutnoga stanovništva $-11,7 \%$, što je signifikantno više od stope depopulacije ukupnoga i prisutnoga stanovništva Hrvatske u cjelini. S obzirom na vrijednost stope depopulacije najveće smanjenje stanovništva u ta dva međupopisja zabilježila je Vukovarsko-srijemska, dok je najmanji demografski pad ostvarila Brodsko-posavska županija. Korisno je upozoriti da je u odnosu na 1961. do 2011. godine samo Osječko-baranjska županija ostvarila skroman demografski porast $(2,8 \%)$, dok su se ostale istočnohrvatske županije depopulirale u rasponu od -33,5 \% (Virovitičko-podravska) do -7,1 \% (Vukovarsko-srijemska), što ukazuje na izraženu prostornu homogenost depopulacijskih trendova i procesa u posljednjih pola stoljeća.

Ulaskom u XXI. stoljeće negativni demografski trendovi nisu usporeni, a još manje zaustavljeni, nego se primjećuje ubrzanje prirodnoga pada stanovništva, jačanje emigracijske komponente u ukupnom kretanju stanovništva te produbljenje demografskoga starenja, s vrlo lošim perspektivama demografskog oporavka. Opća depopulacija i parcijalni depopulacijski procesi zahvatili su većinu naselja, gradova i općina te sve županije Istočne Hrvatske, a to svojega odraza ima na mnoge segmente života i rada čovjeka, institucija i organizacija, uključujući, dakako, i Katoličku Crkvu, osobito u kontekstu potreba i mogućnosti pastoralnoga rada.

Jedan od važnijih parcijalnih depopulacijskih procesa koji s pravom držimo izrazito negativnom odrednicom ukupnoga kreta- 


\begin{tabular}{|c|c|c|c|c|c|c|c|c|}
\hline 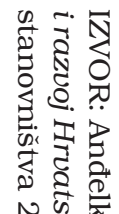 & 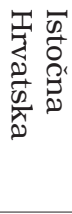 & 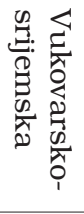 & 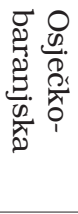 & 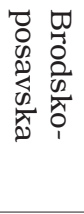 & 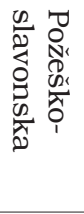 & 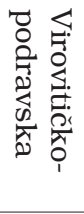 & 孞 & 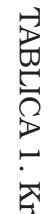 \\
\hline 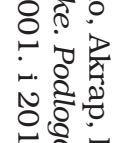 & $\begin{array}{l}0 \\
0 \\
\dot{c} \\
\dot{c} \\
0\end{array}$ & $\begin{array}{l}\text { जo } \\
\omega \\
N \\
N \\
\end{array}$ & $\begin{array}{l}\omega \\
N \\
\infty \\
0 \\
\delta \\
\text { ज }\end{array}$ & $\begin{array}{l}\overrightarrow{0} \\
+ \\
\dot{0} \\
0\end{array}$ & $\begin{array}{l}0 \\
0 \\
\omega \\
1 \\
0\end{array}$ & $\begin{array}{l}\vec{N} \\
\text { v } \\
\text { or }\end{array}$ & 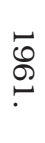 & . \\
\hline 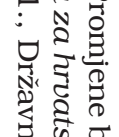 & $\begin{array}{l}0 \\
0 \\
0 \\
i \\
0 \\
\infty\end{array}$ & $\begin{array}{l}\stackrel{N}{*} \\
\stackrel{v}{v} \\
\text { v }\end{array}$ & 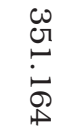 & 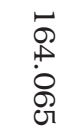 & 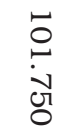 & \begin{tabular}{l} 
而 \\
$\dot{\omega}$ \\
\multirow{1}{*}{}
\end{tabular} & $\begin{array}{l}\text { అै } \\
\text { v }\end{array}$ & 苞. \\
\hline 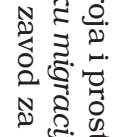 & $\begin{array}{l}0 \\
0 \\
+ \\
0 \\
\infty \\
\infty\end{array}$ & 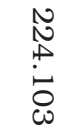 & $\begin{array}{l}w \\
\text { o } \\
\text { No } \\
\infty \\
\infty\end{array}$ & 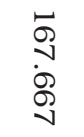 & $\begin{array}{l}0 \\
\vdots \\
\dot{0} \\
0\end{array}$ & 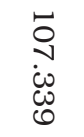 & $\begin{array}{l}\varpi 0 \\
\infty \\
\bullet\end{array}$ & . \\
\hline 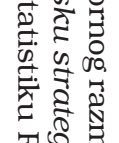 & $\begin{array}{l}0 \\
\text { J } \\
\text { cu } \\
0\end{array}$ & N & 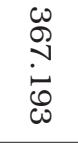 & $\begin{array}{l}ت \\
\stackrel{7}{*} \\
0 \\
\infty \\
\infty\end{array}$ & $\begin{array}{l}0 \\
\vdots \\
\dot{c} \\
\oplus \\
\triangleright\end{array}$ & $\begin{array}{l}\text { o } \\
\vdots \\
\text { o } \\
\text { o }\end{array}$ & $\begin{array}{l}0 \\
\bullet \\
\bullet\end{array}$ & 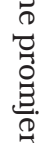 \\
\hline 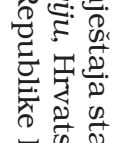 & \begin{tabular}{l}
$\infty$ \\
0 \\
\multirow{0}{0}{} \\
0
\end{tabular} & $\begin{array}{l}\text { N } \\
\wp \\
\text { ○े } \\
\infty\end{array}$ & $\begin{array}{l}\omega \\
\text { ஸे } \\
0 \\
\text { ஸे } \\
\varnothing\end{array}$ & $\begin{array}{l}\text { जै } \\
\text { ơ } \\
\text { o } \\
\text { ज }\end{array}$ & $\begin{array}{l}\infty \\
\dddot{c} \\
\infty \\
\infty \\
0\end{array}$ & $\begin{array}{l}0 \\
\omega \\
\dot{\omega} \\
\infty \\
0\end{array}$ & $\begin{array}{l}0 \\
\text { ○ } \\
?\end{array}$ & 预 \\
\hline 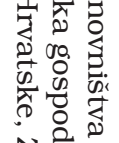 & $\begin{array}{l}\infty \\
0 \\
01 \\
0 \\
0 \\
\infty\end{array}$ & $\begin{array}{l}\text { जै } \\
\text { uै } \\
\text { ज̃ }\end{array}$ & 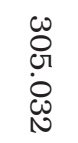 & $\begin{array}{l}\text { जr } \\
\infty \\
0 \\
\text { जे }\end{array}$ & $\begin{array}{l}\searrow \\
\infty \\
\dot{0} \\
\infty \\
\perp\end{array}$ & $\begin{array}{l}\infty \\
+ \\
\infty \\
c \infty \\
\infty\end{array}$ & $\begin{array}{l}\text { No } \\
\text { • }\end{array}$ & $\begin{array}{l}0 \\
0 \\
0 \\
0 \\
0 \\
0 \\
0\end{array}$ \\
\hline 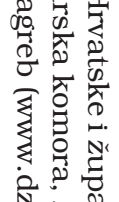 & $\begin{array}{l}\text { ○ } \\
\infty \\
\text { iv }\end{array}$ & $\begin{array}{l}\text { ש̋ } \\
v \\
v\end{array}$ & ま & 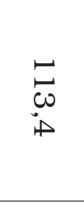 & $\begin{array}{l}0 \\
0 \\
0\end{array}$ & 尔 & 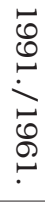 & $\begin{array}{l}\text { ne } \\
\vdots \\
0 \\
0 \\
0 \\
0 \\
0 \\
0 \\
0 \\
0 \\
0\end{array}$ \\
\hline 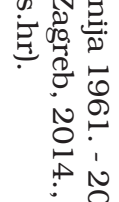 & $\begin{array}{l}\infty \\
N \\
\text { "ir }\end{array}$ & $\begin{array}{l}\text { vै } \\
\text { ò }\end{array}$ & $\begin{array}{l}\infty \\
\omega^{\infty} \\
-1\end{array}$ & $\begin{array}{l}0 \\
0 \\
0\end{array}$ & $\begin{array}{l}\text { D } \\
\text { ơ }\end{array}$ & $\stackrel{\infty}{\llcorner}$ & 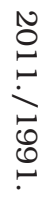 & 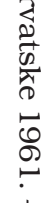 \\
\hline 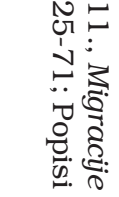 & $\begin{array}{l}\infty \\
\bigcup^{\infty} \\
\square\end{array}$ & $\begin{array}{l}0 \\
0 \\
0\end{array}$ & $\begin{array}{l}0 \\
\stackrel{N}{v}\end{array}$ & 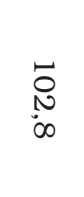 & $\begin{array}{l}\text { D } \\
\text { هి }\end{array}$ & $\begin{array}{l}\text { S } \\
\text { or }\end{array}$ & 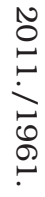 & 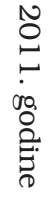 \\
\hline
\end{tabular}


Vladimir Dugalić, Dražen Živić, Moralno-pastoralno djelovanje Crkve pred ...

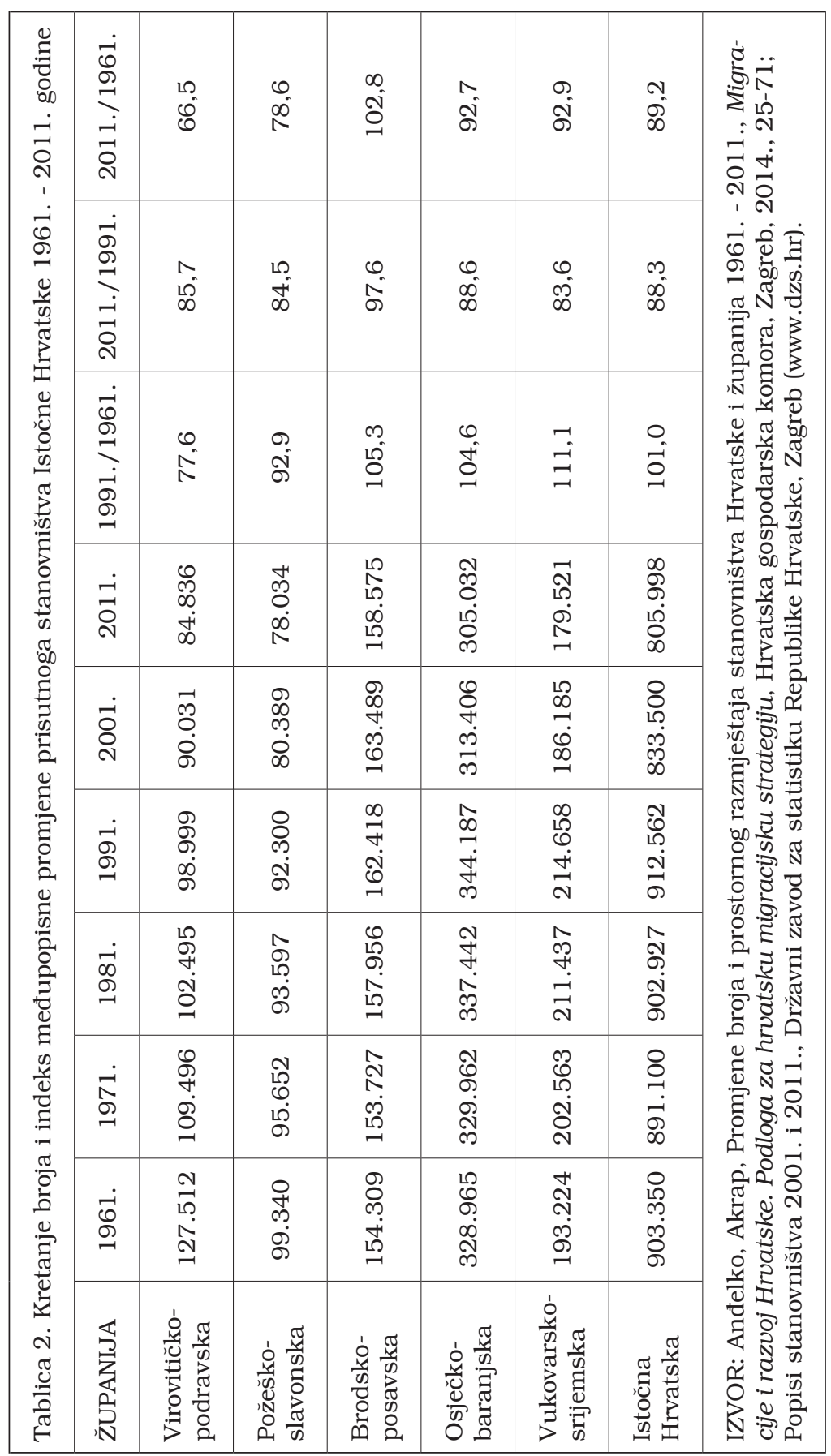


nja stanovništva, ali i oblikovanja vitalnih (bioloških) demografskih struktura (dob/spol) jest prirodna depopulacija, koju za posljednja dva desetljeća (2001. - 2018.) zorno ilustriraju podatci u tablici 3.

Tablica 3. Prirodno kretanje stanovništva Istočne Hrvatske 2001. - 2018. godine

\begin{tabular}{|c|c|c|c|c|}
\hline Godina & Živorođeni & Umrli & $\begin{array}{l}\text { Prirodna } \\
\text { promjena }\end{array}$ & $\begin{array}{l}\text { Vitalni } \\
\text { indeks }\end{array}$ \\
\hline 2001. & 8.750 & 10.020 & -1.270 & 87,3 \\
\hline 2002. & 8.386 & 10.351 & -1.965 & 81,0 \\
\hline 2003. & 8.043 & 10.614 & -2.571 & 75,8 \\
\hline 2004. & 8.024 & 10.136 & -2.112 & 79,2 \\
\hline 2005. & 8.622 & 10.561 & -1.939 & 81,6 \\
\hline 2006. & 8.197 & 10.385 & -2.188 & 78,9 \\
\hline 2007. & 8.163 & 10.827 & -2.664 & 75,4 \\
\hline 2008. & 8.450 & 10.708 & -2.258 & 78,9 \\
\hline 2009. & 8.561 & 10.718 & -2.157 & 79,9 \\
\hline 2010. & 7.866 & 10.768 & -2.902 & 73,0 \\
\hline 2011. & 7.655 & 10.433 & -2.778 & 73,4 \\
\hline 2012. & 7.784 & 10.654 & -2.870 & 73,1 \\
\hline 2013. & 7.384 & 10.183 & -2.799 & 72,5 \\
\hline 2014. & 7.177 & 10.303 & -3.126 & 69,7 \\
\hline 2015. & 6.632 & 10.842 & -4.210 & 61,2 \\
\hline 2016. & 6.439 & 10.251 & -3.812 & 62,8 \\
\hline 2017. & 6.213 & 10.434 & -4.221 & 59,5 \\
\hline 2018. & 6.104 & 10.275 & -4.171 & 59,4 \\
\hline 2011. - 2018. & 55.388 & 83.375 & -27.987 & 66,4 \\
\hline 2001. - 2018. & 138.450 & 188.463 & -50.013 & 73,5 \\
\hline
\end{tabular}

IZVOR: Priopćenja o prirodnom kretanju stanovništva Hrvatske, DZSRH, Zagreb (www.dzs.hr).

Ne ulazeći detaljnije u navedenu problematiku, dovoljno je upozoriti na činjenicu da je u promatranom razdoblju u županijama Istočne Hrvatske živorođeno ukupno 138.450 djece, umrle su ukupno 188.463 osobe, pa je ostvareno prirodno smanjenje (ili „višak” umrlih nad živorođenima) od -50.013 stanovnika, što je na godišnjoj razini prosječni demografski gubitak prirodnim putem od čak 2,8 tisuća osoba. Vitalni indeks je smanjen sa 87,3 na 59,4 što ukazuje 
na opadajuću bioreprodukciju, ali i na vrlo nepovoljan odnos između rodnosti i smrtnosti stanovništva. Realnom se čini pretpostavka da će ubrzo mortalitet biti dvostruko veći od nataliteta, što će prirodno kretanje činiti sve nepovoljnijom odrednicom ukupnoga kretanja stanovništva.

Prema procjeni Državnoga zavoda za statistiku RH sredinom 2018. godine u pet istočnohrvatskih županija živjelo je 709.789 stanovnika, što u odnosu na procjenu iz 2017. godine predstavlja pad broja stanovnika za 3,1 \%, a u odnosu na procjenu iz 2013. godine smanjenje stanovništva za zamjetnih 10,3 \%. ${ }^{4}$ Usporedimo li procijenjeni broj stanovnika Istočne Hrvatske sredinom 2018. s popisanim 1961. godine, dolazimo do zapanjujućeg podatka prema kojemu je apsolutni iznos demografskoga pada iznosio gotovo 200 tisuća stanovnika, a stopa ukupne depopulacije premašila $-21 \%$, što dovodi do zaključka da je od početka 1960-ih do danas Istočna Hrvatska izgubila više od petine svoje populacije. Riječ je, dakle, o jakom demografskom pražnjenju determiniranom nepovoljnim utjecajem obje dinamičke sastavnice ukupnoga kretanja stanovništva - i prirodnim padom i negativnim saldom migracije.

Uzmemo li u izračun samo razdoblje 2011. - 2018. godine (tablica 4), na temelju službenih podataka hrvatske vitalne i (necjelovite) migracijske statistike proizlazi da su sve istočnohrvatske županije na godišnjoj razini zabilježile negativnu demografsku bilancu kao rezultat brojnijeg umiranja od rađanja i većega iseljavanja od doseljavanja, uz važnu činjenicu da je u svim županijama negativan saldo ukupne migracije znatno važniji čimbenik smanjivanja stanovništva od prirodnoga pada.

Prirodno je smanjenje stanovništva od 2011. do 2018. godine iznosilo -28.087, a mehaničko smanjenje -72.006 stanovnika, pa je demografska bilanca bila negativna i iznosila je -100.093 stanovnika. U svim je istočnohrvatskim županijama negativan saldo ukupne migracije činio više od 60 \% negativne demografske bilance: najmanje u Osječko-baranjskoj (65,2 \%), a najviše u Vukovarskosrijemskoj županiji (76,9 \%). To znači da su suvremene migracije destabilizacijski čimbenik aktualnih demografskih kretanja, ali i negativna odrednica drugih društvenih i ekonomskih gibanja na hrvatskom istoku. ${ }^{5} \mathrm{U}$ tom smislu važno je upozoriti na činjenicu da istočnohrvatske županije bilježe negativan saldo i unutarnje (među-

4 Izvor: Procjene stanovništva Republike Hrvatske u 2018. Priopćenje 7. 1. 3., DZSRH, Zagreb, 2019.

5 Dražen Živić, Suvremena migracija kao odrednica depopulacije istočne Hrvatske (2001. - 2014.), u: Sociokulturno nasljeđe i gospodarski razvoj, Sveučilište Josipa 
Tablica 4. Demografska bilanca stanovništva Istočne Hrvatske 2011. 2018. godine po županijama

\begin{tabular}{|l|c|c|c|c|c|}
\hline$Z ̌$ Zupanija & $\begin{array}{c}\text { Prirodna } \\
\text { promjena }\end{array}$ & $\begin{array}{c}\text { Saldo } \\
\text { ukupne } \\
\text { migracije }\end{array}$ & $\begin{array}{c}\text { Demograf- } \\
\text { ska bilanca }\end{array}$ & $\begin{array}{c}\text { Prirodna } \\
\text { promjena } \\
(\%)\end{array}$ & $\begin{array}{c}\text { Saldo } \\
\text { ukupne } \\
\text { migracije } \\
(\%)\end{array}$ \\
\hline $\begin{array}{l}\text { Virovitičko- } \\
\text { podravska }\end{array}$ & -3.380 & -7.159 & -10.539 & 32,1 & 67,9 \\
\hline $\begin{array}{l}\text { Požeško- } \\
\text { slavonska }\end{array}$ & -2.852 & -8.416 & -11.268 & 25,3 & 74,7 \\
\hline $\begin{array}{l}\text { Brodsko- } \\
\text { posavska }\end{array}$ & -4.851 & -15.229 & -20.080 & 24,2 & 75,8 \\
\hline $\begin{array}{l}\text { Osječko- } \\
\text { baranjska }\end{array}$ & -10.596 & -19.985 & -30.481 & 34,8 & 65,2 \\
\hline $\begin{array}{l}\text { Vukovarsko- } \\
\text { srijemska }\end{array}$ & -6.408 & -21.317 & -27.725 & 23,1 & 76,9 \\
\hline
\end{tabular}

županijske) i vanjske migracije, što znači da je odseljavanje iz njih brojnije od doseljavanja, pa one imaju prevladavajuće egzodusne migracijske karakteristike (tablice 5, 6 i 7).

\begin{tabular}{|l|l|l|l|l|}
\hline \multicolumn{5}{|l|}{$\begin{array}{l}\text { Tablica 5. Saldo unutarnje migracije stanovništva Istočne Hrvatske } \\
\text { 2001. - 2018. godine po županijama }\end{array}$} \\
\hline Županija & $\begin{array}{l}\text { Doseljeni iz } \\
\text { drugih hrvat- } \\
\text { skih županija }\end{array}$ & $\begin{array}{l}\text { Odseljeni u } \\
\text { druge hrvat- } \\
\text { ske županije }\end{array}$ & $\begin{array}{l}\text { Saldo } \\
\text { unutarnje } \\
\text { migracije }\end{array}$ & $\begin{array}{l}\text { Koeficijent } \\
\text { unutarnje } \\
\text { migracije }\end{array}$ \\
\hline $\begin{array}{l}\text { Virovitičko- } \\
\text { podravska }\end{array}$ & 7.706 & 13.443 & -5.737 & 57,3 \\
\hline $\begin{array}{l}\text { Brodsko- } \\
\text { posavska }\end{array}$ & 7.563 & 13.255 & -5.692 & 57,1 \\
\hline $\begin{array}{l}\text { Požeško- } \\
\text { slavonska }\end{array}$ & 12.571 & 25.148 & -12.577 & 50,0 \\
\hline $\begin{array}{l}\text { Osječko- } \\
\text { baranjska }\end{array}$ & 22.909 & 33.058 & -10.149 & 69,3 \\
\hline $\begin{array}{l}\text { Vukovarsko- } \\
\text { srijemska }\end{array}$ & 16.179 & 31.658 & -15.479 & 51,1 \\
\hline
\end{tabular}

Jurja Strossmayera u Osijeku, Poljoprivredni fakultet, Odjel za kulturologiju, Ekonomski fakultet, Osijek, 2016., 52-75. 
Vladimir Dugalić, Dražen Živić, Moralno-pastoralno djelovanje Crkve pred ...

\begin{tabular}{|l|l|l|l|l|}
\hline \multicolumn{5}{|l|}{$\begin{array}{l}\text { Tablica 6. Saldo vanjske migracije stanovništva Istočne Hrvatske } \\
\text { 2001. - 2018. godine po županijama }\end{array}$} \\
\hline Županija & $\begin{array}{l}\text { Doseljeni iz } \\
\text { inozemstva }\end{array}$ & $\begin{array}{l}\text { Odseljeni u } \\
\text { inozemstvo }\end{array}$ & $\begin{array}{l}\text { Saldo } \\
\text { vanjske } \\
\text { migracije }\end{array}$ & $\begin{array}{l}\text { Koeficijent } \\
\text { vanjske } \\
\text { migracije }\end{array}$ \\
\hline $\begin{array}{l}\text { Virovitičko- } \\
\text { podravska }\end{array}$ & 3.616 & 8.723 & -5.107 & 41,5 \\
\hline $\begin{array}{l}\text { Brodsko- } \\
\text { posavska }\end{array}$ & 9.950 & 15.438 & -5.488 & 64,5 \\
\hline $\begin{array}{l}\text { Požeško- } \\
\text { slavonska }\end{array}$ & 2.958 & 8.819 & -5.861 & 33,5 \\
\hline $\begin{array}{l}\text { Osječko- } \\
\text { baranjska }\end{array}$ & 11.050 & 24.865 & -13.815 & 44,4 \\
\hline $\begin{array}{l}\text { Vukovarsko- } \\
\text { srijemska }\end{array}$ & 9.711 & 22.688 & -12.977 & 42,8 \\
\hline
\end{tabular}

IZVOR: Priopćenja o migraciji stanovništva Republike Hrvatske, DZSRH, Zagreb (www.dzs.hr).

\begin{tabular}{|c|c|c|c|c|}
\hline Županija & Doseljeni & Odseljeni & $\begin{array}{c}\text { Saldo } \\
\text { ukupne } \\
\text { migracije }\end{array}$ & $\begin{array}{l}\text { Koeficijent } \\
\text { ukupne } \\
\text { migracije }\end{array}$ \\
\hline $\begin{array}{l}\text { Virovitičko- } \\
\text { podravska }\end{array}$ & 11.322 & 22.166 & -10.844 & 51,1 \\
\hline $\begin{array}{l}\text { Brodsko- } \\
\text { posavska }\end{array}$ & 17.513 & 28.693 & -11.180 & 61,0 \\
\hline $\begin{array}{l}\text { Požeško- } \\
\text { slavonska }\end{array}$ & 15.529 & 33.697 & -18.438 & 46,1 \\
\hline $\begin{array}{l}\text { Osječko- } \\
\text { baranjska }\end{array}$ & 33.959 & 57.923 & -23.964 & 58,6 \\
\hline $\begin{array}{l}\text { Vukovarsko- } \\
\text { srijemska }\end{array}$ & 25.890 & 54.346 & -28.456 & 47,6 \\
\hline
\end{tabular}

Primjerice, koeficijent unutarnje migracije (tablica 4) pokazuje da je, s izuzetkom Osječko-baranjske županije, u ostalim istočnohrvatskim županijama broj odseljenih u druge hrvatske županije gotovo dvostruko veći od broja doseljenih; apsolutni se demografski 
gubitak zbog negativnog salda unutarnje migracije kretao u rasponu od -5.692 u Brodsko-posavskoj do - 15.479 stanovnika u Vukovarsko-srijemskoj županiji. U cjelini, u Istočnu Hrvatsku se od 2001. do 2018. godine iz drugih hrvatskih županija doselilo 66.928, a odselilo u druge županije 116.562 osobe što daje negativan saldo unutarnje migracije od -49.634 stanovnika. No sumarni podatci za Istočnu Hrvatsku u cjelini nisu u potpunosti pouzdani jer oni u sebi uključuju i preseljavanja između istočnohrvatskih županija što bez interne obrade migracijske statistike nije moguće brojčano iskazati.

Posljednjih godina zamjećuje se jačanje vanjske migracije, a unutar nje naročito jača iseljavanje u inozemstvo. Samo na temelju službenih, ali necjelovitih podataka hrvatske migracijske statistike razvidno je da su se od 2001. do 2018. godine iz pet istočnohrvatskih županija u inozemstvo iselile (najmanje) 80.533 osobe, dok se iz inozemstva doselilo 37.285 osoba, pa je ostvaren negativan saldo vanjske migracije od (najmanje) 43.248 stanovnika. Koeficijent vanjske migracije, s izuzetkom Brodsko-posavske županije, pokazuje da je broj iseljenih $u$ inozemstvo u ostalim županijama Istočne Hrvatske dvostruko veći od broja doseljenih (tablica 6). Drugim riječima, doseljavanje je tek dijelom nadomjestilo demografske gubitke zbog iseljavanja $u$ inozemstvo. A znamo li da se uglavnom iseljava stanovništvo u najpovoljnijoj fertilnoj i radno sposobnoj dobi, onda nije riječ samo o agregatnom gubitku nego i o jakim strukturno-demografskim deficitima koji se u uvjetima niskoga i sve nižega nataliteta teško mogu samorevitalizirati.

Približno 73 \% od naprijed navedenog broja iseljenih u inozemstvo ili, preciznije, 58.679 osoba, to je ostvarilo u razdoblju od 2011. do 2018. godine, što upućuje na sve veće značenje suvremene vanjske emigracije (tablica 6). Najveći su broj iseljenih u inozemstvo $u$ tom razdoblju zabilježile Osječko-baranjska i Vukovarsko-srijemska županija - zajedno nešto više od 35 tisuća osoba. Istodobno, iz inozemstva su se od 2011. do 2018. godine u županije Istočne Hrvatske doselile 12.073 osobe (najviše, također, u Osječko-baranjsku i Vukovarsko-srijemsku županiju - zajedno nešto više od 7,5 tisuća osoba), pa su za razdoblje 2011. - 2018. godine istočnohrvatske županije ostvarile negativan saldo vanjske migracije od (najmanje) 46.606 stanovnika, što je u odnosu na ukupan broj stanovnika 2011. godine 5,8 \%, pri čemu, očekivano, prednjače Osječko-baranjska i Vukovarsko-srijemska županije - zajedno su negativnim saldom vanjske migracije izgubile gotovo 27,6 tisuća stanovnika.

Nažalost, službena hrvatska migracijska statistika nije cjelovita i ne daje punu sliku brojčanog razmjera iseljavanja, napose kad 
je riječ o vanjskoj migraciji. Neka istraživanja pokazuju da je stvarni broj iseljenih iz Hrvatske $u$ inozemstvo možda i do tri puta veći od službenog broja. Ako je to doista tako, onda je aktualna i realna migracijska komponenta trenutnoga i predvidivoga ukupnoga kretanja stanovništva Hrvatske, a na poseban način upravo hrvatskoga istoka, izrazito zabrinjavajuća i dugoročno neodrživa s motrišta društvene stabilnosti i ekonomskog napretka. To potvrđuju i relevantne projekcije stanovništva koje do polovice ovoga stoljeća predviđaju nastavak ukupne depopulacije i još snažnije demografsko pražnjenje istočnohrvatskoga prostora. ${ }^{6}$ To pred sve društvene aktere, a tako i mjesnu Crkvu, postavlja velike izazove i neizvjesne, a tako potrebne, putove oporavka i opstanka.

\subsection{Nužnost pronatalitetnih i gospodarskih mjera}

Ne ulazeći u analizu svih uzroka koji su doveli do ovakve situacije, dovoljno je istaknuti da je ona, prije svega, posljedica neravnomjernoga regionalnog razvoja. Političke elite dopustile su centralizaciju zemlje te su izostala kapitalna ulaganja koja bi otvorila nova radna mjesta i nije se, kao u drugim sredinama, razvio privatni sektor. Rezultat je da se sva današnja zaposlenost svodi na rad u javnim i državnim ustanovama, koju često prati politička korupcija. Izostanak agrarne politike i nesigurnost otkupa poljoprivrednih proizvoda, često uvjetovanog i nelojalnom konkurencijom i nekontroliranim uvozom hrane, nedovoljno osmišljeni poticaji za razvoj poljoprivrede, jer su počesto oblik socijalne pomoći, niža cijena rada i male plaće, neujednačena kvaliteta života u gradu i na selu, nezaposlenost i izostanak pravne sigurnosti koju prati i radna i socijalna nesigurnost, samo pogoršavaju postojeće stanje. Drugim riječima, problemi hrvatskoga sela i ovog dijela Hrvatske nisu samo gospodarske naravi, nego da su i izraz dugogodišnje političke nebrige središnjih vlasti za ove krajeve, ali i naslijeđenog mentaliteta koji potiče individualizam, uskogrudne interese na štetu općeg dobra,

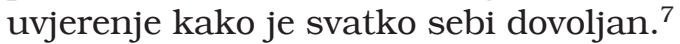

Slavonski biskupi istaknuli su da se sela, ali u sve većoj mjeri i gradovi, svakodnevno sve više demografski prazne, o čemu svjedoči i sve veći broj kuća u kojima nitko ne žive ili su u njima samo samačka i staračka kućanstva. To je opći, sve nepovoljniji okvir, ne samo

6 Detaljnije vidjeti u: Anđelko Akrap, Demografski slom Hrvatske: Hrvatska do 2051., Bogoslovska smotra 85 (2015) 3, 855-868.

$7 \quad$ Usp. Siromaštvo i demografsko stanje u Slavoniji, Baranji i Srijemu. Korizmena poslanica slavonskih biskupa, Đakovo-Požega, 2016., br. 4.6. 
demografskog razvoja nego i društveno-gospodarskog napretka Slavonije, Baranje i Srijema u cjelini. Ako se taj okvir ne promijeni, svako društveno i ekonomsko ulaganje postat će nesigurno i previše rizično, a time se, nažalost, otvara novi i jači krug depopulacije i ekonomskog nazadovanja i siromaštva. „Problemi hrvatskoga sela i ovog dijela Hrvatske nisu stoga samo gospodarske naravi, već zadiru duboko u život naših obitelji i njihovu demografsku budućnost, a povezana su i s pitanjem ekonomske i prehrambene neovisnosti zemlje, skrbi za okoliš kao i nacionalne sigurnosti, jer velika područja uz granicu ostaju bez stanovništva."8 Radi prevladavanja nastale situacije poziva se na duh solidarnosti i socijalne osjetljivosti, njegovanje poduzetničkog mentaliteta i izgradnju socijalne duhovnosti. Na osobit se način ističe kako je potrebno „pojedince, kao i manje skupine, pomagati na način koji će ih osposobiti za samostalno djelovanje, usmjereno na samopomoć i zajedničko dobro". ${ }^{9}$

Ipak, možemo reći da se posljednjih godina vide određeni pomaci, a velike nade polažu se u „Projekt Slavonija”. Međutim, iako se osjećaju prvi pozitivni učinci većih ulaganja u Slavoniju, blagi porast plaća i životnog standarda, sve veća ulaganja u urbanu i ruralnu infrastrukturu, sve očitije je da to nije dovoljno da se zaustavi val iseljavanja. Naime, iako su ulaganja u infrastrukturu, osobito prometnu, obrazovnu, energetsku, hvalevrijedna ulaganja, ona neće polučiti značajnije rezultate ako ta ulaganja ne prati i razvoj industrije, osobito prerađivačke, na koju će se potom osloniti i razvoj poljoprivrede na selima. Bez otvaranja novih radnih mjesta nema značajnijeg razvoja. Osim toga, bez kvalitetne demografske i pronatalitetne te selektivne i kontrolirane migracijske politike neće se zaustaviti negativna demografska kretanja te će se i nadalje osjeća-

$8 \quad$ Isto, br. 2. U svjetlu socijalnog nauka Crkve biskupi u poslanici navode cijeli niz mogućih mjera kojima bi se zaustavila depopulacija i iseljavanje stanovništva, osobito zbog loših uvjeta života, siromaštva i nesigurnosti poljoprivredne proizvodnje. Među ostalim, navodi se nužnost donošenja mjera agrarne politike i strategije razvoja poljoprivrede koje bi omogućile poljoprivrednicima lakše snalaženje u okruženju globaliziranog gospodarstva i nelojalne konkurencije, osobito očitovanoj u uvozu jeftinije, ali često nekvalitetne robe. Potom se ističe važnost da se u određivanju poreza poljoprivrednicima ima na umu kako se u poljoprivredi prihodi ostvaruju sporije i da su izloženi većoj neizvjesnosti, pa da vlasnici kapitala radije ulažu sredstva u druge gospodarske grane nego u poljoprivredu, te da im se jamči pravednija cijena otkupa. Napominje se i nužnost promjene zakonskih okvira i poticanje na zadružnu kulturu rada, kao i važnost primjerenog socijalnog osiguranja i socijalne zaštite jer su prihodi poljoprivrednika redovito niži od primanja radnika u industriji ili namještenika u javnoj službi. Usp. isto, br. 8-14.

Isto, br. 19. 
ti manjak radno sposobnog stanovništva kao i stručnog osoblja te visokoobrazovanih ljudi koji mogu biti pokretači boljitka i napretka.

Stoga valja pozdraviti brojne inicijative lokalnih zajednica. Hvalevrijedan je projekt Ministarstva za demografiju, obitelj, mlade i socijalnu politiku, koji potiče suradnju između predstavnika jedinica lokalne i područne (regionalne) samouprave JLP(R)S, Ministarstva i znanstvenika iz područja demografije i srodnih područja. Cilj je ovog projekta prikupiti i objaviti podatke o demografskim mjerama koje se provode sa svrhom stjecanja uvida u različite mjere i aktivnosti koje se provode na lokalnoj i županijskoj razini, kako bi se omogućila razmjena informacija te učinkovito koordiniranje demografskih mjera koje se provode i planiraju na razini države. ${ }^{10}$

U posljednje vrijeme svjedoci smo tako brojnih ulaganja u infrastrukturu i usluge namijenjene djeci. Takvo ulaganje ima neosporno utjecaj i na širu zajednicu te zajedno s pronatalitetnim politikama na nacionalnoj i lokalnoj razini pridonosi stvaranju preduvjeta za ostanak obitelji u zajednici. U duhu supsidijarnosti, gradovi i općine postaju partneri državnoj vlasti jer svojom pronatalitetnom politikom ublažavaju nepovoljne demografske trendove, a istodobno se smanjuju postojeće regionalne nejednakosti i osigurava ravnomjeran razvoj svih gradova i općina u Republici Hrvatskoj. Valja pohvaliti i ulaganja u obnovu postojećih objekata dječjih vrtića te poboljšanje njihovih materijalnih uvjeta kao i povećanje prostornih kapaciteta kao i ulaganje u besplatne programe učenja stranih jezika, osobito putem tableta i računalnih aplikacija, za polaznike vrtića predškolske dobi kao i omogućavanje besplatnog boravka u jaslicama i vrtiću te povećanje plaća zaposlenicima. ${ }^{11} \mathrm{U}$ tom smi-

10 Usp. Doprinos JLP(R)S demografskoj revitalizaciji Slavonije, Baranje i Srijema. Knjižica sažetaka konferencije održane u Đakovu, 21. svibnja 2019., u organizaciji Ministarstva za demografiju, obitelj, mlade i socijalnu politiku i Grada Đakova, Đakovo, 2019.

11 Pojedine lokalne zajednice, u granicama svojih proračunskih mogućnosti, pokrenule su programe Kolica za klinca, koji uključuju jednokratnu novčanu pomoć roditeljima za svako novorođeno dijete. U pojedinim općinama pokreću se i programi Paketa za bebe u kojima se nalaze potrepštine za majku i dijete $\mathrm{u}$ prvim tjednima života, poput odjevnih i higijenskih potrepština. Kako bi se roditeljima olakšalo školovanje djece, pohvaliti je i sve veća izdvajanja županijskih sredstava za sufinanciranje školske prehrane, osiguravanje besplatnih udžbenika, bilježnica i likovnih mapa te sufinanciranje ili omogućavanje besplatnog prijevoza učenika i studenata. U pojedinim sredinama omogućeno je srednjoškolcima pohađanje besplatnih priprema za državnu maturu, a sve je više lokalnih zajednica koje izdvajaju novčana sredstva za nagrađivanje najboljih srednjoškolaca te za studentske stipendije, osobito za one iz obitelji s troje ili više djece. Usp. isto, 10-16. 
slu sve su veća izdvajanja županijskih sredstava za sufinanciranje školske prehrane, osiguravanje besplatnih udžbenika te bilježnica i likovnih mapa te sufinanciranje ili omogućavanje besplatnog prijevoza učenika i studenata. U pojedinim sredinama omogućeno je srednjoškolcima pohađanje besplatnih priprema za državnu maturu, a sve je više lokalnih zajednica koje izdvajaju novčana sredstva za nagrađivanje najboljih srednjoškolaca te za studentske stipendije, osobito za one iz obitelji s troje ili više djece.

Među mjerama pronatalitetne politike osobito treba istaknuti primjere lokalnih zajednica koje su u mogućnosti osigurati mjere poticanja kupnje prve nekretnine mladim bračnim parovima ili osiguravaju subvenciju u izgradnji stanova iz programa poticane stanogradnje. U nekim sredinama, sve one koji se odluče stanovati u ruralnim mjestima, bilo da u tim mjestima žele graditi nove objekte ili rekonstruirati stare kuće, oslobađa se plaćanja komunalnog doprinosa i komunalne naknade. Među poticajne mjere možemo ubrojiti i sufinanciranje energetske obnove obiteljskih kuća. Naime, porezna reforma, kao i sredstva iz fondova Europske unije, omogućili su da se dio sredstava usmjeri i na mjere socijalne i demografske politike, kao i mjere poticanja gospodarstva te na programe samozapošljavanja dugotrajno nezaposlenih osoba. Hvalevrijedne su i socijalna samoposluživanja za one najugroženije, kao i uskrsnice za umirovljenike, božićnice za nezaposlene te sufinanciranje rada zdravstvenih ustanova kao i subvencije socijalno ugroženim i starijim domaćinstvima. ${ }^{12}$

12 Vrijedno je spomenuti program Zaželi, koji omogućuje pomoć starim i nemoćnim osobama u njihovim kućama, a istodobno omogućuje i zapošljavanje većeg broja žena. Predlaže se, kao nužna mjera demografske i pronatalitetne politike, ostvarenje mogućnosti „majke odgojiteljice”. Naime, zbog sve zahtjevnijeg tržišta rada, koje osobito u nepovoljan položaj stavlja žene, često se od njih zahtijeva da moraju birati hoće li se ostvariti kao majke ili sačuvati radno mjesto. Uvođenjem ove mogućnosti stvorilo bi se pozitivno ozračje i ženama, koje to žele, pomoglo da se lakše odluče za majčinstvo. Naime, nisu rijetki slučajevi da upravo zbog opredjeljenja za majčinstvo žene danas ostaju bez posla. To navodi na zaključak da hrvatsko tranzicijsko društvo nije pronašlo prikladan odgovor na položaj žene na tržištu rada te da ne postoji primjereno vrednovanje njezinog rada u kući te često, zbog obveza koje ima kao žena i majka, dolazi do njezine preopterećenosti, koja se onda odražava i na cjelokupan obiteljski život. Stoga nas ne smije začuditi da sve veći broj žena ne želi djecu te da raste broj onih koji smatraju da su troškovi života preskupi ako se roditelji odluče za veći broj djece. Više o prijedlozima demografskih mjera, vidi: Pero Aračić, Što čini Crkva za brak i obitelj i što bi se moglo mijenjati?, u: Pero Aračić (ur.), Kamo ide istočna Hrvatska?, 162-165. 
Vladimir Dugalić, Dražen Živić, Moralno-pastoralno djelovanje Crkve pred ...

\section{Moralno-Pastoralno DJElovanje MJesnih CRKava}

Sve dosad navedeno stavlja Crkvu na prostoru Istočne Hrvatske pred nove moralno-pastoralne izazove. S jedne strane, moraju se pronaći odgovori na sve češće obiteljske migracije i iznaći novi oblici pastoralne skrbi za iseljene, a, s druge strane, načini kako pomoći obiteljima, osobito s više djece, kako poticati mentalitet u kojem se dijete promatra kao dar, a ne kao teret za obitelj. Reorganizacija pastorala braka i obitelji te karitativnog djelovanja nameću se stoga kao prioriteti pastoralnog rada. Osim toga, izazov je i organizacija pastoralnog rada u uvjetima kada se u mnogim župama smanjio broj vjernika te je sve više župnih zajednica koje nisu u mogućnosti samostalno uzdržavati svoje župnike.

\subsection{Izazovi obiteljskih migracija i pastoralna skrb za iseljene}

Pozivajući se na dokumente Drugoga vatikanskog sabora, u Uputi o pastoralnoj brizi za migrante Kongregacije za biskupe naznačeno je da je „čovjekovo prirodno pravo da se koristi materijalnim i duhovnim dobrima 'kako bi potpunije i lakše došao do vlastitog savršenstva'. Kada pak neka država zbog nedostatka sredstava i velikog broja građana ne može svojim stanovnicima osigurati takva dobra ili postavlja uvjete koji povređuju ljudsko dostojanstvo, čovjek ima pravo iseliti, izabrati u inozemstvu novi dom i steći dostojne uvjete života”. ${ }^{13}$ Naime, takvo pravo ne pripada samo pojedinim osobama nego i čitavim obiteljima. Zato migracije treba urediti tako da se „potpuno osigura zajednički obiteljski život”, ${ }^{14}$ vodeći računa o obiteljskim potrebama što se tiče stana, odgoja djece, uvjeta rada, društvene sigurnosti, itd. ${ }^{15}$ Drugim riječima, poduzetnički duh mora biti popraćen mjerama natalitetne i demografske politike. ${ }^{16}$

Obiteljske migracije postale su stvarnost u svim zemljama svijeta. Kompendij socijalnog nauka Crkve ističe da u sadašnjem svijetu, „u kojemu se pogoršava neravnoteža između bogatih i siromašnih

13 Kongregacije za biskupe, Uputa o pastoralnoj brizi za migrante, Kršćanska sadašnjost, Zagreb, 1969., br. 7. Usp. Drugi vatikanski sabor, Pastoralna konstitucija o Crkvi u suvremenom svijetu Gaudium et spes, u: Drugi vatikanski sabor, Dokumenti, Kršćanska sadašnjost, Zagreb, 2008., br. 26.65.69.

14 Drugi vatikanski sabor, Dekret o apostolatu laika Apostolicam actuositatem, u: Drugi vatikanski sabor, Dokumenti, br. 11. Usp. Sveta Stolica, Povelja o pravima obitelji, Kršćanska sadašnjost, Zagreb, 1983., čl. 12.

15 Kongregacije za biskupe, Uputa o pastoralnoj brizi za migrante, br. 7.

16 Usp. Vladimir Dugalić, Obitelj i tržište rada u svjetlu socijalnog nauka Crkve, u: Pero Aračić (ur.), Kamo ide istočna Hrvatska?, 182-216. 
zemalja i u kojemu razvoj komunikacija brzo smanjuje udaljenosti, povećavaju se seljenja osoba u potrazi za boljim životnim uvjetima, koje dolaze iz manje povlaštenih područja zemlje: njihov dolazak $u$ razvijene države često se shvaća kao prijetnja za visoke razine blagostanja postignute zahvaljujući desetljećima gospodarskog rasta. Ipak, useljenici u većini slučajeva odgovaraju radnoj potrebi koje bi inače ostala nezadovoljena, u sektorima i na područjima u kojima mjesne radne snage nema dovoljno ili nije spremna pružiti svoj radni doprinos” ${ }^{17}$ Pri tome se naglašava da „institucije zemalja domaćina moraju brižno bdjeti da se ne proširi napast iskorištavanja inozemne radne snage, lišavajući je prava zajamčenih domaćim radnicima, koja moraju biti osigurana svima bez diskriminacija". ${ }^{18}$ Nužno je stoga poštivati kriterije jednakosti i ravnoteže kako bi se došlo do toga da se uključivanja u doseljeno društvo odvijaju pod jamstvima koja zahtijeva dostojanstvo ljudske osobe. Drugim riječima, useljenici moraju biti prihvaćeni kao osobe te im se mora pomoći da se, zajedno sa svojim obiteljima, integriraju (uključe) u društveni život. ${ }^{19}$

Socijalni nauk Crkve stoga ne zabranjuje obiteljske migracije $u$ potrazi za boljim i sigurnijim radnim mjestom, budući da su mobilnost i fleksibilizacija radnog mjesta nove i nužne pojave na tržištu rada, ali ističe da je potrebno, prije svega, „pospješiti sve one uvjete koji pružaju veće mogućnosti rada u područjima vlastita porijekla". ${ }^{20}$ To znači da se pred Crkvu stavljaju nove zadaće. S jedne strane, pozvana je, prije svega, snagom proročko-evangelizacijskog poslanja pozivati obitelji da ostanu u svojoj zemlji i tu grade svoju budućnost zauzimajući se u svjetlu socijalnog nauka Crkve za opće dobro i pravednu raspodjelu dobara u društvu, odnosno, zahtijevajući od političkih vlasti odgovornu pronatalitetnu i demografsku politiku koja će ohrabrivati ostanak na rodnoj grudi. Crkva je stoga pozvana poticati na povratak te bi hvalevrijedno bilo u svakoj župi načiniti adresar iseljenih i s njima ne izgubiti kontakt.

Zanimljiva je i ideja o pokretanju projekta Otkrijmo ljubav prema svome mjestu, sa svrhom da se u mladih ljudi probudi svijest o ljepoti življenja na slavonskim prostorima i na taj način zaustavi njihov odlazak u druge krajeve ili zemlje. To, međutim, zahtijeva i potrebu većeg broja stručnih i formativnih tečajeva koji će odgajati vjernike u duhu socijalnog nauka Crkve i poticati na zauzetost

17 Papinsko vijeće „Iustitia et pax”, Kompendij socijalnog nauka Crkve (2004.), Kršćanska sadašnjost, Zagreb, 2005., br. 297.

18 Isto, br. 298.

19 Usp. Katekizam Katoličke Crkve, HBK-Glas Koncila, Zagreb, 1994., br. 2241.

20 Papinsko vijeće „Iustitia et pax”, Kompendij socijalnog nauka Crkve, br. 298. 
u ostvarivanju općeg dobra i duha pravednosti. Naime, zadaća na uspostavi pravednog poretka u društvu vlastita je vjernicima laicima, koji su pozvani osobno sudjelovati u javnom životu i promicati opće dobro, poštujući njegovu legitimnu autonomiju te surađivati s ostalim građanima sukladno svojim kompetencijama i ispunjavajući vlastite odgovornosti. Velik doprinos u tome mogu pružiti katoličke udruge koje ne smiju biti svrha samima sebi i mjesta ugodnog druženja, nego zajednice koje će osmišljavati putove evangelizacije u skladu sa svojim poslanjem i svrhom postojanja. Potrebno je nadići osjećaje pasivnosti i komotnosti te više ulagati u sebe i osobni razvoj i napredak, kako duhovni tako i profesionalni.

S druge strane, Crkva ne može priječiti obiteljima odlazak u, za njih, bolju budućnost ako za to imaju opravdan razlog (nezaposlenost, siromaštvo, nesigurno radno mjesto, itd.). Međutim, i u tom slučaju Crkva ih ne smije ostaviti same, već je dužna osigurati im duhovno-pastoralnu pomoć, kao i pružanje drugih oblika pomoći koje su primjerene njihovim pravim potrebama, osobito u prevladavanju kulturnih razlika. Upravo zbog ovoga gledišta „u pojam migracija obuhvaćeni su svi oni koji iz bilo kojeg razloga moraju izbivati izvan domovine i izvan vlastite etničke zajednice te im je uistinu nužna potreba posebne pomoći”. ${ }^{21}$ Vrijedno je stoga istaknuti veliku važnost i odgovornost koju imaju hrvatske katoličke misije u Europi i svijetu, ne samo u duhovno-pastoralnom smislu nego i u prihvaćanju i solidarnoj pomoći novopridošlim članovima njihovih zajednica. U tom smislu, Đakovačko-osječka nadbiskupija poslala je svećenika u Dublin (Irska) kako bi se ondje organizirala nova katolička misija, budući da je velik broj iseljenih pojedinaca i obitelji iz Istočne Hrvatske upravo tamo pronašao svoj novi dom i radno mjesto. U konačnici, mjesne Crkve će se morati suočiti i s useljeničkom politikom i pripremiti se za prihvat useljenika koji će $\mathrm{k}$ nama dolaziti iz različitih zemalja, pa i onih drugačijega kulturološkog mentaliteta i vjere.

\subsection{Pastoral braka i obitelji i karitativno djelovanje u ozračju depopulacije}

Gotovo sva provedena znanstvena istraživanja upućuju na zaključak da hrvatsko društvo još uvijek visoko cijeni vrijednost braka i obitelji, ${ }^{22}$ ali da na trend sve manjeg broja djece u obiteljima

21 Kongregacije za biskupe, Uputa o pastoralnoj brizi za migrante, br. 15.

22 Usp. Marijan Valković, Sociološko istraživanje: Vjera i moral u Hrvatskoj. Djelomično izvješće, Bogoslovska smotra 68 (1998.) 4, 461-473; Marijan Valković, Gordan Črpić, Ivan Rimac, Vjera i moral u Hrvatskoj. Pregled posto- 
ponajviše utječu dva čimbenika: loša gospodarska i financijska situacija popraćena sve većom nezaposlenošću i rastućim siromaštvom, ali i promjena mentaliteta, koji sve više postaje individualistički te prednost daje višem životnom standardu u odnosu na dijete. Takav mentalitet dijete više ne prihvaća kao dar koji istodobno ispunjava i bračnu ljubav samih roditelja, budući da ona po svojoj naravi teži da bude plodna. ${ }^{23}$ Dijete, „ne dolazi izvana da se pridoda uzajamnoj ljubavi supružnika; niče iz samog srca njihova uzajamnog dara kojemu je plod i dovršenje", ${ }^{24}$ odnosno, izričaj je velikodušnosti odgovornog roditeljstva.

To upućuje na činjenicu da, osim gospodarskih uvjeta, i promjena mentaliteta snažno utječe na smanjenje broja djece $u$ obitelji. Komparativna analiza vrednota u Hrvatskoj i u Europi pokazala je da je u Hrvatskoj posljednjih godina značajno opao broj onih koji smatraju da žena treba imati djecu da bi se osjećala ispunjenom. Utjecaj modernizacije učinio je da je 2008. godine taj stav zastupalo 45,1 \% građana u odnosu na rezultate provedenih istraživanja iz 1999. i 2001., kada je broj onih koji smatraju da žena treba imati djecu kako bi ispunila pravi smisao svoga postojanja iznosio 55,3 $\% .{ }^{25}$ To potvrđuje činjenicu da sela, iako su još uvijek brojnija od gradova, nisu više „u vlasništvu” većinske populacije. Naime, od 6759 naselja u Hrvatskoj prema popisu iz 2001. samo je 124 gradskih naselja dok su 6635 sela i zaseoci. Međutim, u ovih 124 grada živi $69 \%$ stanovnika, a u ostalim naseljima oko $31 \% .{ }^{26} \mathrm{~S}$ druge stra-

taka i aritmetičkih sredina (mean) istraživanja, Bogoslovska smotra 68 (1998.) 4, 483-511; Pero Aračić, Gordan Črpić, Krunoslav Nikodem, Vjerska situacija u hrvatskom tranzicijskom društvu prema istraživanju „Aufbruch”, Vjesnik Đakovačke i Srijemske biskupije 128 (2000.) 12, 775-815; Pero Aračić, Gordan Črpić, Krunoslav Nikodem, Postkomunistički horizonti. Obrisi sustava vrijednosti i religijskih orijentacija u deset postkomunističkih zemalja, Đakovo, 2003.; Josip Baloban (ur.), U potrazi za identitetom. Komparativna studija vrednota: Hrvatska i Europa, Zagreb, 2005.; Josip Baloban, Krunoslav Nikodem, Siniša Zrinščak (ur.), Vrednote u Hrvatskoj i u Europi. Komparativna analiza, Kršćanska sadašnjost Katolički bogoslovni fakultet Sveučilišta u Zagrebu, Zagreb, 2014; Gordan Črpić, Jasna Čurković Nimac, Željko Tanjić, Vjersko uvjerenje i moralno ponašanje, Kršćanska sadašnjost - Hrvatsko katoličko sveučilište, Zagreb, 2016.

23 Usp. Vladimir Dugalić, Obitelj i tržište rada u svjetlu socijalnog nauka Crkve, u: Pero, Aračić (ur.), Kamo ide istočna Hrvatska?, 170-182.

24 Katekizam Katoličke Crkve, br. 2366.

25 Usp. Krunoslav Nikodem, Ivan Štengl, Stavovi o djeci i promijenjene uloge žena i muškaraca u srednjoj i istočnoj Europi, u: Josip Baloban, Krunoslav Nikodem, Siniša Zrinščak (ur.), Vrednote u Hrvatskoj i u Europi. Komparativna analiza, 174.

26 Usp. Antun Šundalić, Selo - iz autentičnosti u neprepoznatljivost. Prilog sociološkom istraživanju ruralnosti Slavonije i Baranje, Osijek, 2010., 80. 
ne, na temelju dostupnih podataka, u Republici Hrvatskoj je samo $11 \%$ obitelji s troje djece, što je ispod europskog prosjeka (13\%) te demografi već više desetljeća upozoravaju da se naše društvo suočava, unatoč pozitivnom stavu prema braku i obitelji, sa sve većim padom nataliteta i zabrinjavajućom demografskom krizom, koja onemogućuje daljnji razvoj društva i uzrokuje dugoročne i teške posljedice, kako za gospodarstvo, tako i za društvo u cjelini. ${ }^{27}$

Navedeni rezultati stoga upućuju da hrvatsko društvo postupno razvija urbanu kulturu, što će se dugoročno odraziti i stavove građana prema obitelji i broju djece. Naime, u hrvatskom društvu sve više raste duh individualizma, koji možemo promatrati kao rastuću autonomiju pojedinca u razvijanju vlastitih vrijednosti koje će biti oslobođene, ali ne uvijek u potpunosti, utjecaja religije i tradicionalnih moralnih normi. Životni stavovi sve se više temelje na osobnom izboru i sve manje ovise o tradiciji i vjerskoj pripadnosti. Rezultati istraživanja pokazuju da se u Hrvatskoj, u razdoblju od 1999. do 2008., smanjio broj onih koji djecu shvaćaju kao smisao života (sa $76,3 \%$ na 66,2 \%) te kao obvezu prema društvu (sa 50,3 \% na 23,9 $\%){ }^{28}$ Očekivati je da će se sa sve većim rastom urbane kulture polako mijenjati i stav prema braku i obitelji. Opadat ce postotak onih koji visoko vrednuju brak i obitelj te imaju načelnu otvorenost prema većem broju djece, a dodatnu poteškoću stvara i činjenica da

27 U Hrvatskoj je od godine 1971. do 1991. porastao broj obitelji s jednim djetetom (8,8 \%) i obitelji s dvoje djece (33,5\%), dok je smanjen broj obitelji s troje ili više djece (33,5 \%). Tako je popisom stanovništva iz 1991. godine utvrđeno da od ukupnog broja bračnih parova s djecom obitelji s jednim djetetom čine 45,8 $\%$, obitelji s dvoje djece čine $43,5 \%$, te obitelji s troje i više djece samo $10,7 \%$. S druge strane, povećao se broj obitelji bez djece. Osim toga, od 1991. do 2000. godine rođeno je samo 462512 djece (1971. - 1980. rođeno je 625264 djece, a od 1981. do 1990. rođeno je 596297 djece), što je smanjenje od $26 \%$, odnosno 22,4 \%. Istodobno se povećao broj umrlih, sa 462521 (1971. - 1991.) na 509 449 (1991. - 2000.) ili 10,1 \%. Tako je došlo do prirodnog smanjenja u iznosu od -53 867 stanovnika u razdoblju od 1991. do 2000. godine. Naime, od 1991. do 2000. godine ukupni mortalitet iznosio je 516 379, što je 53867 više umrlih u odnosu na broj živorođene djece u tom razdoblju. Drugim riječima, potkraj 20. stoljeća rađalo se prosječno 1,38 dijete po obitelji, a za generacijsko obnavljanje ukupnog stanovništva potrebno je da taj broj iznosi barem 2,1 prosječno po obitelji. Usp. Hrvatska biskupska konferencija, Direktorij za obiteljski pastoral Crkve u Hrvatskoj, Kršćanska sadašnjost, Zagreb, 2002., br. 35.

28 Usp. Krunoslav Nikodem, Ivan Štengl, Stavovi o djeci i promijenjene uloge žena i muškaraca u srednjoj i istočnoj Europi, u: Josip Baloban, Krunoslav Nikodem, Siniša Zrinščak (ur.), Vrednote u Hrvatskoj i u Europi. Komparativna analiza, 183. 
mladi danas sve kasnije stupaju u brak, kao i podatak o sve većem broju neženjenja. ${ }^{29}$

Drugim riječima, val iseljavanja koji je zahvatio Slavoniju, Baranju i Srijem te pad nataliteta bitni su čimbenici aktualnih demografskih kretanja, ali i negativnih odrednica drugih društvenih i ekonomskih gibanja na hrvatskom istoku. Suočena s ovim izazovima Crkva je pozvana pružiti evangelizacijski navještaj socijalne duhovnosti koju prati i veća socijalna osjetljivost za čovjeka u potrebi. Potrebno je izgrađivati snažniju svijest o solidarnosti i osobne odgovornosti te se založiti za izgradnju „kulture solidarnosti” nasuprot sve prisutnijem konzumerizmu i individualističkom stilu života. Snagom proročko-evangelizacijskog poslanja, Crkva ima zadaću promicati „kulturu života”, jer, kako ističu dokumenti Crkve, pad nataliteta je, prije svega, odraz moralne krize društva i plod potrošačkog mentaliteta i konzumerizma, koji na brak i obitelj gleda kao na prolaznu i potrošnu stvar. ${ }^{30}$ Dijete se uvijek mora promatrati kao dar, a ne kao ekonomski čimbenik koji roditeljima treba osigurati sigurnu mirovinu u starosti. Međutim, svjesni smo da svaka promjena mentaliteta mora poći, prije svega, iz obitelji, jer je ona povlašteno mjesto odgoja za rad, marljivost, štedljivost i druge socijalne kreposti. U tom smislu, same obitelji su pozvane na samoorganiziranje u svrhu zaštite svojih naravnih i neotuđivih prava. Crkveni dokumenti pozivaju sve članove Crkve da kršćansko učenje o braku i obitelji ne smije prestati nadahnjivati i preoblikovati ljude u društvu upravo u svjetlu te poruke ljubavi i nježnosti, odnosno pozvani su prenositi „evanđelje obitelji”. ${ }^{31} \mathrm{U}$ tom smislu vrijedno je istaknuti i doprinos što ga pružaju razne udruge, poput Zajednice bračnih susreta te bračna i obiteljska savjetovališta. Ljepotu obitelji potrebno je povezati i s borbom protiv pobačaja te osnažiti i podržati djelovanje udruga koje se bore za svetost, nepovredivost i dostojanstvo ljudskog života.

29 O rezultatima znanstveno-istraživačkog projekta Kršćanski identitet $i$ kvaliteta bračnog i obiteljskog života (282-0000000-0780) Katoličkoga bogoslovnog fakulteta u Đakovu Sveučilišta J. J. Strossmayera u Osijeku, o stavovima koji ponajviše na odluku o roditeljstvu, vidi: Pero Aračić, Ivo Džinić, Biljana Hlavaček (ur.), Kršćanski identitet i obitelj, Katolički bogoslovni fakultet u Đakovu, Đakovo, 2011.

30 Usp. Ivan Pavao II., Apostolska pobudnica o zadaćama kršćanske obitelji u suvremenom svijetu Familiaris consortio - Obiteljska zajednica, Kršćanska sadašnjost, Zagreb, 1981., br. 6-7; Franjo, Posinodalna apostolska pobudnica o ljubavi u obitelji Amoris Laetitia - Radost ljubavi, Kršćanska sadašnjost, Zagreb, 2016., br. 32-35.

31 Usp. Franjo, Posinodalna apostolska pobudnica Amoris Laetitia, br. 72, 80-83. 
Pronalaženje novih oblika pastorala braka i obitelji postaje stoga sve hitnija zadaća. Crkva ima obvezu još snažnije se zauzeti u promicanju dostojanstva i vrijednosti braka i obitelji te određenim potporama podržavati otvorenost životu, osobito vrednovanjem i potporom obitelji s više djece. Crkva u Istočnoj Hrvatskoj danas to čini ponajviše osnivanjem katoličkih osnovnih i srednjih škola te vjerskih vrtića, jer se na taj način ne samo pomaže roditeljima u odgoju njihove djece, nego se dugoročno pridonosi i odgoju za nesebično zauzimanje u promicanju općeg dobra. Osim toga, svakodnevno su sve brojniji fondovi za stipendiranje izvrsnih učenika i studenata te osobito onih slabijeg imovinskog stanja. Sve su prisutnije i različite inicijative koje promiču vrijednosti braka i obitelji, poput župnog Dana obitelji, Dana bračnih jubileja, kao i biskupove nazočnosti na krštenju u obiteljima s više djece. ${ }^{32}$

U cilju što bolje priprave na sakrament ženidbe i kasnijega bračnog i obiteljskog života te odgoja djece, potrebno je domisliti dugoročniji oblik priprave na sklapanje ovog sakramenta. Iskustva pokazuju da bi priprava na ženidbu trebala trajati barem jednu godinu, jer postoji 'produženo zaručništvo' te mladi sve kasnije ulaze u brak. Od iznimne je stoga važnosti da tečajevi priprave za brak budu što kvalitetniji, osobito na način da se potaknu bračni supružnici da tijekom tih susreta posvjedoče mladim osobama snagu ovoga sakramenta kao znak koji ne samo da pokazuje „koliko je Krist ljubio svoju Crkvu u savezu zapečaćenom na križu, nego također

32 Vrijedno je spomenuti proširenje projekta Hrvatskog Caritasa „Pomozimo zajedno”, Zakladu „Dr Nikola Dogan” i korizmenu inicijativu „75 za 1” Caritasa Đakovačko-osječke nadbiskupije te Zakladu Požeške biskupije za pomoć učenicima i studentima, kao i korizmenu akciju „Djeca djeci”, u kojoj djeca u kutijice koje dobiju na početku korizme skupljaju svoj novčani prilog. Pomoć se najčešće sastoji u nabavi školskog pribora, plaćanju podstanarstva, školarina, prijevoza, režijskih troškova, kredita, odjeće i obuće, troškova obroka i smještaja u đačkim i studentskim domovima te plaćanju lijekova i troškova liječenja. Hvalevrijedne su i inicijative u pojedinim župnim zajednicama kojima se pomažu učenici i studenti slabijeg imovnog stanja ili su izričaj potpore uspjesima i ostvarenjima onih nadarenih. Hvalevrijedna je i inicijativa poput hodočašća obitelji s brojnom djecom u Voćin u prigodi proslave Uznesenja BDM. Međutim, uočava se da nije dovoljna jednokratna pomoć roditeljima na krštenju, nego da ih potrebno materijalno i moralno pratiti i poslije sakramenta krštenja i to na duže staze. Caritas Požeške biskupije tijekom cijele godine provodi i akciju Kruh i mlijeko za svaki dan kao i Akciju prikupljanja starog papira u koju su uključene brojne fizičke i pravne osobe. Sav prihod namijenjen je za pomoć djeci. „Božić u nama” je glazbeno-kulturni program u organizaciji Caritasa Požeške biskupije i mladih Župe sv. Terezije Avilske u Požegi. Navedeni program je humanitarnog karaktera za pomoć određenoj obitelji ili pojedincu u potrebi. Usp. http://caritas.djos.hr/ aktivnosti (28.07.2020.); https://pozeska-biskupija.hr/2017/08/03/caritaspozeske-biskupije/ (28.07.2020.). 
uprisutnjuje tu ljubav u zajedništvu supruga. Združujući se u jedno tijelo, oni predstavljaju sjedinjenje Sina Božjega s ljudskom naravi”. ${ }^{33}$ Potrebno je stoga ponuditi duže oblike uvođenja u vjeru, koji bi snažnije naglasili Božju zamisao o braku i obitelji i mlade obitelji pripremili na odgovorno roditeljstvo te na sustavan način, a ne prigodnim vatrogasnim mjerama, mijenjali mentalitet i stvarati ozračje u kojem će se vrednovati majčinstvo i očinstvo te odgovornost roditelja za odgoj i budućnost vlastite djece. ${ }^{34}$ Roditeljstvo je Božji poziv te sustvaranje novog ljudskog bića nije „privatno poduzetništvo”. Svjesni smo da sve to zahtjeva i određeni broj osposobljenih, stručnih suradnika za pastoral braka i obitelji koji bi pomogli svećenicima i župnicima. Zasigurno, kako to ističe i papa Franjo, to mogu ponajbolje ostvariti oni koji žive taj sakrament i na temelju poslanja iz tog sakramenta. ${ }^{35}$ Stoga su hvale vrijedni napori koje u tom smjeru ulažu naše crkvene obrazovne institucije, osobito pokretanjem novih programa stručnih i specijalističkih studija koji ce osposobljavati vjernike laike za pastoral braka i obitelji, kao i na izradu i osmišljavanje novih programa sustavnog rada $\mathrm{s}$ brakovima i obiteljima. U tom smislu do sada su vrijedan doprinos pružili specijalistički studiji Katoličkoga bogoslovnog fakulteta u Đakovu Sveučilišta u Osijeku te osobito Škola za župne suradnike Đakovačko-osječke nadbiskupije. ${ }^{36}$

Osnivanjem Caritasovih pučkih kuhinja ublažavaju se posljedice sve većeg osiromašenja, osobito umirovljenika i nezaposlenih građana. Međutim, želimo li odgovoriti na današnje izazove, karitativno djelovanje mora nadrasti prigodno djelovanje i ponuditi socijalne programe koji će omogućiti stručno prekvalificiranje i mogućnost ekonomskog osamostaljenja, odnosno lakše zaposlenje. Nameće se i potreba izrade projekata socijalnog poduzetništva kojima bi se financijski pomoglo onim osobama koje imaju kvalitetne i održive projekte za pokretanje nekog oblika poduzetništva. To podrazumijeva i zahtjevnu zadaću preustroja današnjeg djelovanja biskupijskih Caritasa, a u tome značajnu pomoć mogu pružiti župni Caritasi, osobito u pronalaženju osoba i obitelji korisnika socijalnog poduzetništva te u prosudbi kriterija za dodjelu financijske pomoći. Osim toga, u selima, ali u sve većoj mjeri i u gradovima Istočne Hrvatske,

33 Franjo, Posinodalna apostolska pobudnica Amoris Laetitia, br. 73.

34 Usp. Pero Aračić, Što čini Crkva za brak i obitelj i što bi se moglo mijenjati?, u: Pero Aračić (ur.), Kamo ide istočna Hrvatska?, 159-161.

35 Usp. Franjo, Posinodalna apostolska pobudnica Amoris Laetitia, br. 208.-211, 287.-289.

36 Usp. Kalendar susreta 2020./2021. Đakovačko-osječke nadbiskupije, Đakovo, 2020., 39. 
sve su brojnija samačka i staračka kućanstva te je potrebno domisliti i pastoral starih i nemoćnih osoba te osnažiti oblike socijalne i karitativne pomoći. Vrijedan doprinos u tome pružaju katoličke udruge, poput Veronikinog rupca ${ }^{37}$ i Marijine legije, ${ }^{38}$ kao i brojni župni Caritasi. ${ }^{39}$

\section{ZAKLJUČAK}

Iz svega rečenoga razvidno je da se Istočna Hrvatska danas suočava sa sve većim valom iseljavanja koji, uz već više desetljeća snažnu depopulaciju, ove krajeve stavlja u vrlo nepovoljnu situaciju. Naime, u razdoblju od 2011. do 2018. godine istočnohrvatske županije ostvarile su negativan saldo vanjske migracije od (najmanje) 46.606 stanovnika što je u odnosu na ukupan broj stanovnika 2011. godine 5,8 \%, pri čemu, očekivano, prednjače Osječko-baranjska i Vukovarsko-srijemska županija. Međutim, neka istraživanja pokazuju da je stvarni broj iseljenih iz Hrvatske $u$ inozemstvo možda i do tri puta veći od službenog broja. Pred državne i civilne vlasti, kao i pred Crkvu, postavljeni su stoga novi izazovi, ali i odgovornost prema povjerenim im zadaćama. Na političkim vlastima je obveza donošenja dugoročnih pronatalitetnih i gospodarskih mjera koje će stvoriti pozitivno ozračje za ostanak i tako zaustaviti val iseljavanja, ali i depopulaciju stanovništva. Crkva je, u skladu sa svojim proročko-evangelizacijskim poslanjem, pozvana naviještati „evanđelje obitelji” i „kulturu života”, odnosno istinu o dostojanstvu kršćanskog braka i obitelji te mijenjati individualistički mentalitet koji u djeci ne vidi više dar, nego teret. Osim toga, osnaživanjem i reorganizacijom karitativnog djelovanja koji će nadrasti prigodno djelovanje, pozvana je izgrađivati „kulturu solidarnosti” i pomoći onima najugroženijima, poput nezaposlenih i siromašnih, odnosno, ranjivim i socijalno ugroženim skupinama. Pozvana je ponuditi socijalne programe prilagođene novim potrebama tržišta rada, ali i rastućem siromaštvu, te moralno-pastoralnim djelovanjem poticati odgovorno roditeljstvo i pružati pomoć obiteljima s više djece. Nameće se stoga i potreba

37 O djelovanju udruge Veronikin rubac u Osijeku vidi: http://www.veronikinrubac.hr/ (27. 7. 2020).

38 O djelovanju u Župi sv. Ćirila i Metoda u Osijeku (posjetima bolesnicima u župi, udomiteljskoj ustanovi u Frankopanskoj ulici te Domu za psihički bolesne odrasle osobe u Čepinu) vidi više: http:/ /www.cirilimetod.hr/pastoralne-grupe/ marijina-legija.html (27. 7. 2020.).

39 O projektu „Kućni hospicij” Caritasa Župe Ivankovo vidi: http://djos.hr/donacijabolnickih-kreveta-zupnom-caritasu-iz-ivankova/ (27. 7. 2020.). 
osmišljavanja novih oblika pastorala braka i obitelji te priprave za ovo odgovorno poslanje i zadaću.

Crkva ne može i ne smije spriječiti obiteljske migracije u potrazi za boljim radnim mjestom i sigurnijom budućnošću, ali je pozvana upozoriti da poduzetnički duh mora biti popraćen mjerama natalitetne i demografske politike. Sigurnost radnoga mjesta, pravedna naknada (plaća) za obavljeni posao, rodiljne naknade, ulaganje $\mathrm{u}$ infrastrukturu koja prati zaposlene roditelje, bolja organizacija rada koja omogućuje ženama slobodne dane kada djeca polaze u školu, neradna nedjelja, povoljni stambeni krediti, radno zakonodavstvo koje će zaštititi trudnice i majke od gubitka posla, samo su neke od mjera koje moraju pratiti suvremeno tržište rada. Na selima je potrebna dugoročna agrarna politika i sustav pravedne cijene otkupa, a nužna je i promjena zakonskih okvira. Iako se socijalni nauk Crkve ne protivi radu žena izvan kuće, on upozorava na to da to ne smije ići na štetu njezina naravnog poslanja kao žene i majke, odnosno, zauzima se da im se omogući rad u takvim okolnostima koje se slažu s potrebama i dužnostima supruge i majke. Ostvarenje fleksibilnijeg radnog mjesta ili mogućnost rada od kuće, zasigurno bi pripomoglo mnogim ženama da lakše povežu svoje obiteljske i profesionalne obveze te na taj način istovremeno ostvare dimenziju majčinstva i odgoja djeteta/djece te napredovanja u zvanju i struci. To na žalost nije do sada dovoljno osmišljeno, a ponajmanje riješeno za zadovoljavajući i prihvatljivi način. Izgrađivati „kulturu rada” koja je po mjeri obiteljskog života zadaća je i Crkve i svih društvenih čimbenika. U konačnici, Crkva je pozvana, prije svega, hrabriti i poticati mlade ljude da ostanu u svojim sredinama i bore se za bolju budućnost. Preko inozemne pastve potrebno je pak pratiti one koji su otišli u inozemstvo te im poručiti kako nisu zaboravljeni i da se s radošću čeka njihov povratak. 
Vladimir Dugalić, Dražen Živić, Moralno-pastoralno djelovanje Crkve pred ...

\section{MORAL AND PASTORAL CHURCH ACTIVITIES FACING THE CHALLENGES OF EMIGRATION AND FALLING BIRTH RATES IN EASTERN CROATIA}

\section{Summary}

The east of Croatia is facing an increasing wave of emigration which, with a strong depopulation for several decades, puts these areas in a very unfortunate situation. Therefore, the first part of the paper analyses migration trends and the extent of depopulation as well as the most important causes that led to this situation, and points out some necessary pro-birth and economic measures. Namely, in the period from 2011 to 2018, the eastern Croatian counties achieved a negative balance of external migration of (at least) 46,606 inhabitants, which is $5.8 \%$ of the total population in 2011 , and, as expected, Osijek-Baranja and Vukovar-Srijem counties are in the lead. However, some researches show that the actual number of emigrants from Croatia abroad is perhaps up to three times higher than the official number. The second part of the paper points out the importance of moral-pastoral and social-charitable activities of the Church, particularly in finding answers to the increasing family migrations, but also in finding new forms of pastoral care for emigrants. On the one hand, the Church is called to spiritually and pastorally accompany those who have gone abroad and to tell them that they are not forgotten and that we look forward to their return, and on the other hand, to invite young people and families to stay in their country and build their future here. Moreover, in a situation of strong depopulation, the Church has the task, by the power of her prophetic-evangelizing mission, to promote the "gospel of the family" and to encourage a mentality in which the child is seen as a gift rather than a burden to the family. The reorganization of the pastoral care of marriage and family and finding the new forms of charitable activities arise as priorities of the moral and pastoral activity of the Church.

Keywords: Eastern Croatia, emigration, migration trends, depopulation, pro-birth policy, Catholic Church, family gospel, culture of life, pastoral care of marriage and family, charitable work 